\title{
Career planning for physical disability students
}

\section{Syafrudin Bayu Nusantara, Muya Barida, Erni Hestiningrum, Ariadi Nugraha}

\author{
Universitas Ahmad Dahlan, Yogyakarta, Indonesia \\ muya.barida@bk.uad.ac.id
}

Submitted: 06-04-2020, Revised: 30-07-2020, Accepted: 20-11-2020

\begin{abstract}
Career Planning for Students with Physical Disabilities is crucial to be prepared. A good career planning picture must contain four aspects of career planning which consist of seeking information, understanding, making decisions, and career achievement. The purpose of this study was to explore in-depth career planning in students of the Special School for Physical Disabilities (SLB) 1 Yogyakarta. This study used a qualitative approach, with the type of case study research, the subjects in this study were two students with physical disabilities, the first subject had moderate cerebral palsy and the second subject experienced abnormalities in the muscle system and skin groups. (musculus skeletal system) spina bifida. Then the secondary sources are teachers and parents. The data collection technique used triangulation in the form of interviews, observation, and documentation. The results of the study concluded that the career planning of the two early TA and DI students had differences. TA has not been able to do career planning. Because in the search for information, understanding, decision making, and career skills, TA cannot do it. Meanwhile, DI is capable of career planning because DI can find career information, even though DI is still a little doubtful due to lack of confidence, DI career decision making can be even though it is still not effective in managing free time. DI career skills are said to be capable, even though DI does not attend any additional education (courses).
\end{abstract}

Keywords: Career Planning; Inclusive Education; Independence; Physical Disability

\section{Introduction}

Students with physical disabilities are individuals who experience impaired limb function such as limbs, hands, muscles, joints or other body shapes. This disturbance can result in impaired coordination, communication, adaptation, mobilization and impaired integrity of self-development. The causes of limb dysfunction are congenital or accidental neuromuscular and bone structure disorders, including clams palsy, amputation, polio, and paralysis. A person is said to be physically disabled if his physical condition or physical health interferes with daily activities. Physical disabilities include visual disturbances, cerebral palsy, or other physical impaired disorders (Golding et al., 2008). It should be understood, physical disabilities do not only have mental retardation. They only experience problems in one of their limbs, the rest they are the same as individuals in general who have the same rights in planning a better life (Misbach, 2012). Physical obstruction is defined as any condition that causes sensory or motor impairment, such as visual or hearing impairment, loss of limbs, excessive pain or fatigue, uncontrolled seizures, difficulty breathing, and abnormal or restricted movement, for a continuous period, or not limited (Günel et al., 2014).

This study focused on children with psychological disabilities such as cerebral palsy and spina bifida. Cerebral palsy is a neurodevelopmental disorder associated with gross motor disabilities (Alshryda \& Wright, 2014). These disorders transfer comorbidities with epilepsy, visual disturbances, hearing loss, speech disorders, interaction disorders, and mental retardation (Charitaki \& Papalexopoulou, 2018). Cerebral palsy can be characterized by individual problems that carry out the movement of small parts such as the right leg or left leg or most motor nerves such as full hands and feet caused by congenital neurodevelopmental disorders. Spina bifida is a term congenital disability that occurs for 
several months, or rather, the baby's spine cannot close completely (Luke, 2011). This condition makes it difficult for individuals to make movements.

Based on data obtained from Kompas in 2010 (Merdiasi, 2017) it is stated that the number of individuals with physical barriers in Indonesia is as many as 20 million people, accounting for $80 \%$ or 16 million unemployed. This data shows that there is a significant increase in 2017, where the data reported by the Ministry of Manpower stated that the number of individuals with physical barriers in Indonesia increased to 21 million people, a reduction in the percentage of disabled people in Indonesia was $96.31 \%$. Now only $4 \%$ have not found work. However, this percentage still does not meet the standards set by the world bank, Indonesia is still behind Malaysia by 5\% Singapore 7\%, China $10 \%$ and other countries.

Furthermore, in Yogyakarta in 2018, the Population Statistics Board of D.I Yogyakarta recorded the number of individuals with physical barriers in the second semester of 2018 that the total disability divided into five cities/regencies was 9,599. Whereas in Kulon Progo, a total of 1,147 people, Bantul a total of 1,847 people, Gunung Kidul 3,108 people, Sleman total a total of 1,862 people, and Yogyakarta City a total of 1,635 people (DIY, 2018).

The increasing number of people with disabilities is a new challenge for state institutions, educational institutions, communities and families who are required to fulfil equal rights and obligations. The role of children with disabilities in national development is significant to be considered appropriately and utilized. Besides, facilities and efforts to provide legal protection for the position, rights, obligations and roles of persons with disabilities have been regulated in Law Number 4 of 1997 concerning Persons with Disabilities. This is regulated in-laws and regulations, including human resource issues and national education for persons with disabilities. Some of the main instruments in international law that control the work rights of persons with disabilities, to obtain decent work, require career planning. (Sakban et al., 2019) states that career planning is a process that can be carried out by individuals, and steps taken to achieve career goals. Able to make career plans that require valid, reliable, and accurate career information (Hartono, 2018).

Career planning is crucial for developmentally disabled students. This is so that mentally disabled students can choose and get the right information and be able to apply their interests and talents as expected, to gain career maturity. State that career maturity is an individual's readiness in self-knowledge, career information, integration of self-knowledge with careers, decision making and career planning (Brown \& Lent, 2017). One of the things that affect job is self-concept; if the self-concept is formed, career maturity will be created, which will lead a person to become an individual who is competitive in getting a job.

The results of Handayani et al (2015) about the relationship between self-concept and career efficacy in late adolescents with disabilities, it is known that students with disabilities who are supported by the environment will have a good self-concept so that they dare to aspire to develop a career, of course because they feel able to achieve these goals. . Based on this research, it was also found that on average mentally retarded students have a more positive self-concept than their blind and deaf peers. On the other hand, low career maturity can lead to mistakes in making the right career decisions.

The results of the research by Handayani et al ( 2015) that students with disabilities who are supported by the environment will have a good self-concept so that they dare to aspire to develop a career, of course, because they feel able to achieve these goals. Based on 
this research, it was also found that on average, developmentally disabled students have a more positive self-concept than their blind and deaf peers. On the other hand, low career maturity can lead to mistakes in making the right career decisions.

The mistakes in career decision making will also result in the emergence of problems faced by physical disability, one of which is work discrimination. The issue of workplace discrimination is supported by the results of Setyawati's research (2016) on the description of the struggle for physical disability faced with work discrimination, that each subject in the study has a different fighting power. However, all issues are the same in terms of experiencing work discrimination. The first subject has a fighting power that is not fulfilled correctly so that the results received work become ineffective; the second subject has a high fighting power. It gives a good impact, such as being able to work effectively, and the third subject has a very high fighting ability so that confidence can complete every excellent job. Based on the issue of employment discrimination, educational institutions should need to prepare graduates who can compete and have a high degree of struggle in career planning.

The mistakes in career decision making will also result in the emergence of problems faced by physical disability, one of which is work discrimination. The issue of work discrimination is supported by the results of Setyawati's research (2016) on the description of the struggle for physical disability faced with work discrimination, that each subject in the study has a different fighting power, but all subjects are the same in terms of experiencing work discrimination. The first subject has a fighting power that is not fulfilled properly so that the results received work become ineffective, the second subject has a high fighting power and gives a good impact such as being able to work effectively, and the third subject has a very high fighting ability so that confidence is able to complete every good job. Based on the issue of employment discrimination, educational institutions should need to prepare graduates who are able to compete and have a high degree of struggle in career planning. The facts that exist in the field of career planning for mentally disabled students cannot be fully guaranteed. Most developmentally disabled students have an interest in one type of work, but have low self-confidence in planning themselves to enter a world career.

The problems above come from living in an environment of students with physical disabilities. The assumption that physical disabilities are shameful, embarrassing, considered helpless, considered the same as sick people, pitied, and sometimes just left alone, stay at home and always monitored so that it is challenging to create equal rights and opportunities. The difference in treatment received by mentally disabled students also affects the psychological condition of mentally disabled students, both directly and indirectly, which causes them to feel inferior, embarrassed, pessimistic, and not confident in preparing for a career according to their talents and interests. This underlies the need for career guidance services to help students with physical disabilities plan and have a positive self-concept, so that career maturity is realized (Merdiasi, 2017).

Career guidance is needed to prepare students to face the world of work, and to choose a particular job or occupation/profession and to equip themselves to be ready to occupy the assigned position, and to adapt to the various demands of the job they are entering (Winkel \& Hastuti, 2010). Salahudin explains the purpose of career planning, namely designing life rationally to acquire roles that follow interests, abilities, and socio-economic conditions (Salahudin, 2010). With good career planning, students will feel a sense of satisfaction because the physical disability is suitable, harmonious, and balanced with themselves and their environment in growing and receiving a complete picture of themselves 
and the work that is suitable for them. Career guidance is considered appropriate as an alternative in developing career planning for students with physical disabilities.

Parson et al (Parson et al., 2010) stated that the factors that influence career planning consist of abilities, interests and achievements. The career development of physical disability learners is inseparable from environmental factors, both physical, psychological, and social. The inherent nature of the environment is change. Changes that occur in the background can affect the lifestyle of students with a physical disability. If the difference is difficult to predict, or beyond the scope of ability, it will create a gap in the development of physical disability learners' behaviour.

The career planning of all students, including the physically challenged also needs to be done. Through good career planning, prospects are getting better. This study aims to examine in depth the career planning of physical disability students of SLB Negeri 1 Yogyakarta. Researchers describe factually and objectively about career planning in physical disability students. Career planning consists of four aspects, career information exploration, career understanding, career decision making, and career skills.

\section{Methods}

The approach used in this research is a qualitative approach to the type of case study research. The case study in this study is a series of scientific activities that are carried out intensively, in detail and in-depth about the events, programs and career planning activities of students with physical disabilities at the Yogyakarta Special Education 1 (SLB) State School.

Research subjects in this study using a purposive sampling technique. These considerations consist of 1) mentally disabled students at SLB Negeri 1 Yogyakarta who experience abnormalities in the cerebral system or disorders of the central nervous system such as (cerebral palsy); and 2) mentally disabled students at SLB Negeri 1 Yogyakarta who experience abnormalities in the muscular-skeletal system. The data collected is in the form of career planning for students with physical disabilities. The data sources used were primary sources (students with mental retardation of cerebral palsy and skeletal system muscles) and secondary sources (teachers and parents).

Data collection techniques in this study were moderate participation observation, semistructured interviews, and documentation studies. The research instrument consisted of interview guidelines, observation guidelines, and as a complement to documentation studies. Researchers used a form of source triangulation and technical triangulation. Researchers used a form of source triangulation and technical triangulation. Triangulation of data sources in career planning research aims to examine the data that researchers obtained from three sources, namely mentally disabled students, parents, and teachers. The career planning data for mentally disabled students who were received will be described, categorized, if seen the same if the views are different and specific from the three data sources. Triangulation of techniques in career planning research aims to test the credibility of career planning data for students with a physical disability, which is obtained by researchers from the same source but with different techniques. The techniques used by the researchers consisted of moderate participation observation, semistructured interviews, and documentation studies.

Data analysis technique in qualitative research is the process of systematically compiling and searching for data obtained from semistructured interviews, moderate observations, and documentation studies conducted by researchers. Data analysis in qualitative research is inductive, and the process is done before entering the field, during the process in the area, and after completing the process in the field. The data analysis technique 
used by researchers in the career planning research of physical disability students uses the Miles and Huberman models in Figure 1.

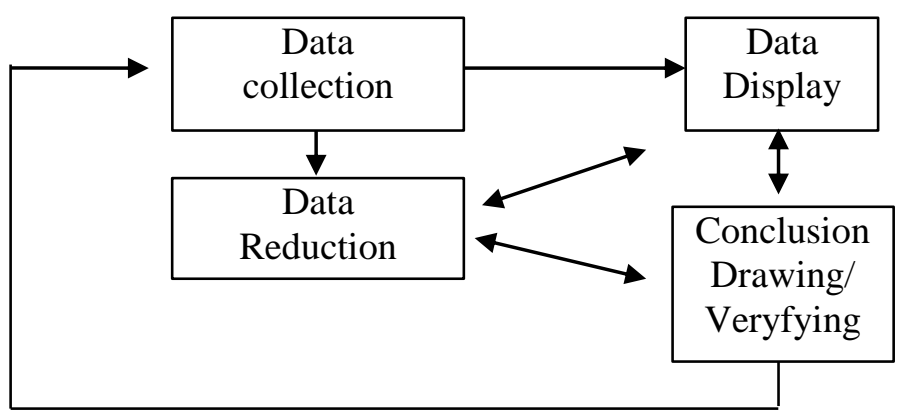

Figure 1. Components of the Miles and Huberman Model data analysis

\section{Results and Discussion \\ Data Reduction}

Subject one (initials TA)

Based on the results of research conducted on TA, the aspects of career planning obtained are as follows.

The first aspect is about career information exploration, and TA can learn career information because it has used career information from various sources and studied it so that it has career understanding. TA has never discussed careers with adults to find out career information that they don't know yet.

The second aspect is about career understanding, and TA does not yet have a curiosity about the desired career conditions because TA has not thought at all about the importance of the chosen career, and about the educational requirements for the desired job that TA already knows.

The third aspect is about career decision making, and TA has not been able to plan what to do after finishing school. Because the descriptions and career goals are still confusing for TA, what TA does is not directly directed at activities that support career success. TA has not been able to use their spare time effectively to participate in activities that support their expected career.

The fourth aspect is about career skills. TA has not attended additional education (courses).TA who have participated in extracurricular activities, but have not thought about using extracurricular activities as a learning medium or adding skills to be used in the expected career achievement. TA has followed the activities held by the school well. However, the skills and knowledge obtained from the training have not been maximally mastered.

Subject two (Initials DI)

Based on the results of research conducted on DI, the aspects of career planning obtained are as follows.

There are four aspects in career planning where the first aspect is about career information exploration, DI is always looking for and studying career information from search results on cellphones using the google and youtube application, and DI often discusses careers with her brother and mother.

The second aspect is about career understanding, DI knows the career he wants to do, but still hesitates because he thinks his physical condition is different from the others. DI 
also already knows the educational requirements for the desired career, but DI's discipline in complying with the rules that apply in schools is still lacking.

The third aspect is about career decision making, DI has career planning; after graduating from school, he wants to become an artist. DI career description and goals are quite mature. DI also knows the opportunities and ways to enter a career as desired. DI is less able to manage their spare time effectively because they often do their jobs lazily.

The last aspect is about career skills, DI has never attended additional education (courses), DI only takes part in extracurricular activities and takes advantage of these activities to improve career skills.

\section{Data Presentation}

Table 1. Presentation of Data

\begin{tabular}{|c|c|c|c|}
\hline Aspect & Indicator & Subject 1 (TA) & Subject 2 (DI) \\
\hline \multirow[t]{2}{*}{$\begin{array}{l}\text { Career } \\
\text { information } \\
\text { exploration }\end{array}$} & $\begin{array}{l}\text { Learning career } \\
\text { information }\end{array}$ & $\begin{array}{l}\text { TA has been able to learn career } \\
\text { information because TA has used } \\
\text { career information obtained from } \\
\text { various sources and knew it so that } \\
\text { he has a career understanding. }\end{array}$ & $\begin{array}{l}\text { DI is always looking for and } \\
\text { studying career information from } \\
\text { search results on cellphones using } \\
\text { the google and youtube } \\
\text { application }\end{array}$ \\
\hline & $\begin{array}{lr}\text { Talking } & \text { about } \\
\text { careers } & \text { with } \\
\text { adults } & \end{array}$ & $\begin{array}{l}\text { TA has never discussed career with } \\
\text { adults to find out career information } \\
\text { that he doesn't know yet. }\end{array}$ & $\begin{array}{l}\text { DI used to discuss or exchange } \\
\text { career thoughts with his older } \\
\text { siblings, parents, and teachers } \\
\text { about his love of painting. }\end{array}$ \\
\hline \multirow[t]{2}{*}{$\begin{array}{l}\text { Career } \\
\text { understanding }\end{array}$} & $\begin{array}{l}\text { Knowing the } \\
\text { desired career } \\
\text { conditions }\end{array}$ & $\begin{array}{l}\text { TA does not yet have a curiosity } \\
\text { about desired career conditions } \\
\text { because TA has not thought at all } \\
\text { about the importance of knowing } \\
\text { desired career conditions. }\end{array}$ & $\begin{array}{l}\text { DI already knew the career he } \\
\text { wanted to go where he wanted to } \\
\text { become a painter, but DI was still } \\
\text { in doubt because he assumed that } \\
\text { his physical condition was } \\
\text { different from others. }\end{array}$ \\
\hline & $\begin{array}{l}\text { Knowing the } \\
\text { educational } \\
\text { requirements for } \\
\text { the desired } \\
\text { career }\end{array}$ & $\begin{array}{l}\text { TA already knows the general } \\
\text { education requirements such as the } \\
\text { rules that apply in schools and has } \\
\text { consulted around education issues } \\
\text { to find out information that was not } \\
\text { previously known. }\end{array}$ & $\begin{array}{l}\text { DI already knows also about the } \\
\text { educational requirements for a } \\
\text { desired career, but DI's discipline } \\
\text { in obeying the rules that apply in } \\
\text { schools is still lacking. }\end{array}$ \\
\hline \multirow[t]{3}{*}{$\begin{array}{l}\text { Career } \\
\text { decision } \\
\text { making }\end{array}$} & $\begin{array}{l}\text { Can plan what } \\
\text { needs to be } \\
\text { done after } \\
\text { finishing school }\end{array}$ & $\begin{array}{l}\text { TA has not been able to plan what } \\
\text { to do after finishing school. } \\
\text { Because the descriptions and career } \\
\text { goals are still confusing for TA, } \\
\text { what TA does is not directly } \\
\text { directed at activities that support } \\
\text { career success. }\end{array}$ & $\begin{array}{l}\text { DI has career planning; after } \\
\text { graduating from school, he wants } \\
\text { to become an artist. and in the } \\
\text { description and career objectives } \\
\text { DI has been said to be mature. }\end{array}$ \\
\hline & $\begin{array}{l}\text { Knowing the } \\
\text { opportunity and } \\
\text { how to enter the } \\
\text { desired career }\end{array}$ & $\begin{array}{l}\text { TA has not been able to know the } \\
\text { opportunities and ways of entering } \\
\text { the desired career, because TA also } \\
\text { does not yet have the picture and } \\
\text { purpose of continuing a career. }\end{array}$ & $\begin{array}{l}\text { DI already knows the } \\
\text { opportunities and ways to enter a } \\
\text { career as desired. DI obtained this } \\
\text { information from the people } \\
\text { around him. }\end{array}$ \\
\hline & $\begin{array}{l}\text { Manage the } \\
\text { time effectively }\end{array}$ & $\begin{array}{l}\text { TA has also not been able to make } \\
\text { use of free time effectively to } \\
\text { participate in activities that support } \\
\text { its expected career. }\end{array}$ & $\begin{array}{l}\text { In managing his free time } \\
\text { effectively, DI could not yet } \\
\text { because he was often lazing about } \\
\text { doing what he was told and DI } \\
\text { was unable to use his free time to } \\
\text { participate in career-supporting }\end{array}$ \\
\hline
\end{tabular}




\begin{tabular}{|c|c|c|c|}
\hline Aspect & Indicator & Subject 1 (TA) & Subject 2 (DI) \\
\hline & & & activities as he had hoped. \\
\hline \multirow[t]{3}{*}{ Career skills } & $\begin{array}{l}\text { Take additional } \\
\text { education } \\
\text { (courses) }\end{array}$ & $\begin{array}{l}\text { TA does not follow additional } \\
\text { education at all (courses) outside his } \\
\text { study hours at school, the career } \\
\text { chosen by TA is still unknown. }\end{array}$ & $\begin{array}{l}\text { DI also does not attend any } \\
\text { additional education (courses) } \\
\text { outside of school hours to support } \\
\text { career, because in dividing free } \\
\text { time DI has not been able to. }\end{array}$ \\
\hline & $\begin{array}{l}\text { Participate in } \\
\text { extracurricular } \\
\text { activities }\end{array}$ & $\begin{array}{l}\text { TA has participated in participating } \\
\text { in extracurricular activities. } \\
\text { However, in participating in } \\
\text { extracurricular activities, TA has } \\
\text { not yet thought about the use of } \\
\text { extracurricular activities as learning } \\
\text { media or adding skills to be used in } \\
\text { the expected career achievements. }\end{array}$ & $\begin{array}{l}\text { DI has also participated in } \\
\text { participating in extracurricular } \\
\text { activities, although only a few } \\
\text { have experienced. And DI can } \\
\text { take advantage of these } \\
\text { extracurricular activities to hone } \\
\text { skills and add career skills. }\end{array}$ \\
\hline & $\begin{array}{l}\text { Following } \\
\text { training related } \\
\text { to the desired } \\
\text { career }\end{array}$ & $\begin{array}{l}\text { TA has followed it well where the } \\
\text { school held the activity. However, } \\
\text { the mastery of the skills and } \\
\text { knowledge gained from the training } \\
\text { activities that have been followed } \\
\text { by TA has not been able to master it } \\
\text { well because the ability to think and } \\
\text { remember TA is a bit late. }\end{array}$ & $\begin{array}{l}\text { DI has followed it well because } \\
\text { the mastery of the skills and } \\
\text { knowledge of the activities that he } \\
\text { participated was able to master } \\
\text { even though he was not totally } \\
\text { mastered, at least DI was able to } \\
\text { master it. }\end{array}$ \\
\hline
\end{tabular}

\section{Conclusion Drawing}

Based on the data analysis, every student has different obstacles in career planning. Judging from these four aspects as follows.

1. Career information exploration, both including children with physical disabilities but with different specifications of the disorder. TA has physical disabilities and has a moderate category of abnormalities in the cerebral system or central nervous system (cerebral palsy). DI has physical disabilities that have abnormalities in the muscle and skeletal system (muscular cell system) with the spina bifida group or irregularities in the spine. To find career information, TA and DI have studied it well from the various sources they can, through smartphones and electronic media, printed media, textbooks and pamphlets, as well as from teachers, parents, and adults around them. But regarding discussing careers with adults, the first TA subject has never been discussed at all, and it is different from the second subject where DI used to discuss or exchange ideas with adults about his favourite career.

2. Career understanding, in career understanding both subjects, both TA and DI have some differences. The difference is that TA is less curious about the career conditions he wants and wants to live in; his condition is the cause of a lack of confidence in determining his career goals. Furthermore, regarding knowing the educational requirements for the desired career, TA already knows in general terms such as the rules that apply in schools, but specifically to the academic requirements according to the profession he wants he does not know at all. This is different from DI, where he already knows about the educational needs for the desired job but disciplined, and DI is still lacking in obeying the rules that apply in schools.

3. Career decision making, in the aspect of career decision making TA, has not been able to plan what to do after completing school because he does not have any prior planning concerning the steps that must be taken after graduating from school. This is different 
from DI, which already has a definite career planning after graduating from school. DI already has plans to become a painter and is preparing the steps for him to take. TA does not know the opportunities and ways to enter the desired career, because he does not have the ideas and goals to continue his career. In the activity of managing free time effectively, both TA and DI subjects have not been able to utilize free time effectively to deepen their abilities according to their desired careers. But the difference is that TA has not been able to take advantage of free time because he does not have the chosen career planning picture, while DI already has the desired career planning picture, which is to become a painter. But it's just that DI is still lazy in utilizing free time to participate in activities that support the career as expected.

4. Career skills, in this last aspect, there are some similarities and differences in the two subjects. The equation on the first subject TA and the second subject DI both have not followed additional education (courses). However, it is crucial to supporting skills related to their chosen careers. TA has participated in extracurricular activities, but only in joining extracurricular activities, TA has not thought about the use of extracurricular activities. DI has also participated in several extracurricular activities, but not all have experienced because some extracurricular activities cannot be followed. In connection with attending training related to the desired career, TA has participated in training activities well. But in terms of mastering the skills and knowledge gained from training activities, TA has not been able to master it well because the ability to think and remember TA is a bit slow. DI has also participated in every training and is relatively good because, in terms of the ability to master the knowledge and skills of the activities that he participated in, he was able to be overwhelmed.

The results of the study concluded that each student has abilities and obstacles or problems that are different from each other in career planning. The readiness of students in career planning following the desired career of the two subjects, the results are quite visible variations in the seriousness and the way they are active in the school and community environment. The first subject (TA), in taking care of himself needs help and assistance specifically by others and Ta does not have a great curiosity in his career and has not thought the importance of knowing the desired career conditions. This is following statements made by TA's parents. The idea is also in line with what was conveyed by Teacher TA.

The second subject DI already has a curiosity in his career as conveyed by Di's parents. He already knows the profession he wants to go through. It's just that Di is still doubtful in the process of realizing the expected career planning because he thinks that his physical condition is different from others. This is consistent with the statement made by parents DI.

Both students have similarities in inhibiting factors in career planning, in which internal conditions become the chief obstacles. Same as stated by Aminurrohim et al (2014) in their research which noted that the most significant barriers to career planning are formed by internal factors, namely intelligence and self-expertise, as well as talents and interests. Talking about career planning, optimistic thinking also significantly affects students in realizing the desired career without dealing with doubts or doubts as the problems faced by subject two as described above. This is in line with the results of research conducted by Lisnawati et al (2016) which stated that there was a significant increase in future orientation in the group given treatment in the form of Optimistic Thinking Training. Training also 
provides skills for adolescents who can compile and have good career planning according to their capacity.

Careful career planning is an essential thing for students to be independent in determining studies, can determine the selection to enter the workforce, can understand information and procedures to support career planning, and understand the various professions that exist in the wider community. The statement is following the results of previous research conducted by Widiyanti (2019) which in his research results stated that the maturity of career planning owned by students as a provision to enter the workforce or continue their studies to a higher education level.

Guidance and Counseling Services have functions including prevention, development and curative procedures. Guidance and counselling in career planning for all students, including those experiencing a physical disability can be a service that consists of essential services, responsive services, individual planning, and system support. For example, career planning can be integrated with a group guidance service which is a critical service in guiding students in the field of developing career types and developing career selection skills. Group guidance services consist of several students so that students can develop and exchange career planning. Besides, career planning can be integrated with individual counselling services which are responsive services to help students who are dealing with technical problems in career selection they are experiencing. Student parents can receive personal counselling services; it is to help parents find their children in preparing career planning. In individual planning services, guidance and counselling teachers can help individuals who need physical learning disabilities for further study or job selection that is appropriate to their abilities, levels, interests, and beliefs. System support is a service required to provide understanding related to physical and individual problems that can determine career choices from various career choices, teacher guidance and counselling to collaborate and collaborate with multiple parties.

\section{Conclusions and Suggestions}

Based on the results of the study, it can be concluded that the career planning abilities of physical disability students vary. TA is said to have not been able in career planning. Because in terms of career understanding, career decision making, and TA career skills can not be done at all. While DI is said to have been able in career planning because DI can already search for career information, career understanding can also though DI still has a little doubt due to lack of confidence, DI career decision making can even though it is still less effective in managing time free. DI career skills are said to have done well, even though DI has not attended any additional education (courses) at all.

Based on the conclusion of each subject, the cases experienced by each developmentally disabled student are said to be different from one another. Preventing and overcoming circumstances of developmentally disabled students can be done by using appropriate services, namely group guidance services. Group guidance can be provided to train, develop and become a means of brainstorming career planning, such as career information is known, career understanding that is owned, career decision-making ability, and finally career skills. Like career information that is known, career understanding possessed career decision-making abilities, and eventually career skills.

\section{References}

Alshryda, S., \& Wright, J. (2014). Development and reliability of a system to classify gross 
motor function in children with cerebral palsy. In Classic Papers in Orthopaedics. 575577.

Aminurrohim, A. W., Saraswati, S., \& Kurniawan, K. (2014). Survei faktor-faktor penghambat perencanaan karir siswa. Indonesian Journal of Guidance and Counseling: Theory and Application, 3(2).

Brown, S. D., \& Lent, R. W. (2017). Social cognitive career theory in a diverse world: Closing thoughts. Journal of Career Assessment, 25(1), 173-180.

Charitaki, G., \& Papalexopoulou, A. (2018). The impact of therapeutic horse riding on motor function and social skills of children with cerebral palsy. Online Submission, 10(1), 1729.

DIY, B. P. S. (2018). Daerah Istimewa Yogyakarta dalam angka 2015. Badan Pusat Statistik Propinsi DI Yogyakarta. 307-308.

Golding, P., Donaldson, O., Tennant, V., \& Black, K. (2008). An analysis of factors affecting the adoption of ICT by MSMEs in rural and urban Jamaica.

Günel, M. K., Türker, D., Ozal, C., \& Kara, O. K. (2014). Physical management of children with cerebral palsy. Cerebral Palsy-Challenges for the Future: IntechOpen, 29-72.

Handayani, P., Adeline, A., \& Irwanto, I. (2015). Hubungan konsep diri dan efikasi karir pada remaja akhir laki-laki penyandang disabilitas. IJDS: Indonesian Journal of Disability Studies, 2(1).

Hartono, M. S. (2018). Bimbingan karier. Prenada Media.

Lisnawati, D. K., Juliani, R., \& Prasetyaningrum, P. (2016). Pelatihan berpikir optimis untuk meningkatkan orientasi masa depan remaja tuna daksa. JIP (Jurnal Intervensi Psikologi), 8(2), 250-262.

Luke, S. D. (2011). The power of strategy instruction evidence for education. Washington, DC: National Dissemination Center for Children with Disabilities. Focus on Exceptional Children, 44(2).

Merdiasi, D. (2017). Gambaran tuna daksa yang bekerja. Noetic Psychology, 3(2), 60-81.

Misbach, D. (2012). Seluk-beluk tunadaksa \& strategi pembelajarannya. Javalitera. Yogyakarta.

Parson, A., Williams, L., Byrd, C., Williamson, M., Pace, A., Clough, H., Williams, B., Parker, M., Johnson, M., \& Eanes, J. (2010). Miscellany [Spring 2010].

Sakban, S., Nurmal, I., \& Ridwan, R. Bin. (2019). Manajemen sumber daya manusia. Alignment: Journal of Administration and Educational Management, 2(1), 93-104.

Salahudin, A. (2010). Bimbingan dan konseling. Bandung: CV. Pustaka Setia.

Sulistyowati, E., \& Setiawati, D. (2016). Pemanfaatan cinema therapy dalam bimbingan kelompok untuk pemahaman tentang meningkatkan perilaku prososial siswa. Jurnal BK UNESA.

Widiyanti, T. (2019). Layanan bimbingan karir dalam upaya meningkatkan kemampuan perencanaan karir pada siswa kelas XII SMK Kesehatan Insan Mulia Yogyakarta tahun ajaran 2018/2019. G-Couns: Jurnal Bimbingan Dan Konseling, 3(2).

Winkel, W. S., \& Hastuti, S. (2010). Bimbingan konseling di institusi pendidikan edisi revisi. Jakarta: Grasindo. 